\title{
Eksistensi Desa Agraris
}

\section{The Existance of an Agrarian Village}

\author{
Budiman $^{1 *}{ }^{*}$ Jumansyah $^{2}$, Sry Reski Mulka ${ }^{3}$, Rinda Eka Santi ${ }^{4}$ \\ ${ }^{1}$ FISIP, Universitas Mulawarman, ${ }^{2}$ FISIP, Universitas Mulawarman, ${ }^{3}$ FISIP, Universitas Mulawarman, ${ }^{4}$ FISIP, Universitas \\ Mulawarman
}

The existence of an agrarian village is an integral part of sustainable regional development. The existence of Mulawarman Village as an agrarian village is the responsibility of the regional government as a dynamic / motivator of the people's aspirations, to support and protect and preserve agrarian villages. The existence of Mulawarman Village as an agrarian village is in fact still a major problem for the local government and the people in the village. This is due to the role of the local government as a dynamic to move the aspirations of rural communities in carrying out development in the village. So that the existence of Mulawarma Village as an agrarian village is endangered. Keywords: Local government, dynamic / mobilizer, agrarian village.

Keywords: Local Goverment, Dynamic/ Mobilizer, Agrarian Village

Keberadaan Desa agraris merupakan bagian integral dalam pembangunan daerah yang berkelanjutan. Keberadaan Desa Mulawarman sebagai desa agraris merupakan tanggung jawab pemerintah daerah sebagai dinamisator/penggerak aspirasi masyarakat, untuk mendukung dan melindungi serta melestarikan desa agraris. Eksistensi Desa Mulawarman sebagai desa agraris saat ini faktanya masih menjadi persoalan utama bagi pemerintah daerah dan masyarakat yang berada di desa tersebut. Hal ini disebabkan belum maksimalnya peran pemerintah daerah sebagai dinamisator untuk mengger-

OPEN ACCESS ISSN 2541-2841 (online) ISSN 2302-6790 (print)

Edited by: Didik Hariyanto

Reviewed by: Tatag Handaka

*Correspondence: Budiman

budiman@fisip.unmul.ac.id

Received: 7 Maret 2019

Accepted: 11 Maret 2019

Published: 1 September 2019

Citation:

B, J, Mulka SR and Santi RE (2019)

Eksistensi Desa Agraris.

Kanal. 8:1.

doi: 10.21070/kanal.v\%vi\%i.3073 akan aspirasi masyarakat pedesaan dalam melakukan pembangunan di desa. Sehingga kemudian eksistensi Desa Mulawarma sebagai desa agraris terancam punah.

Keywords: Pemerintah Daerah, Dinamis/Mobilisator, Desa Agraris

\section{PENDAHULUAN}

Desa Mulawarman merupakan satu dari sekian banyak desa di Kalimantan Timur yang terdampak aktivitas pertambangan batu bara dan pembukaan lahan perkebunan kelapa sawit, perjalanan panjang Desa Mulawarman yang pernah ditetapkan sebagai lumbung padi itu, Produksi sawah saat itu mencapai 5 ton gabah per hektare. Desa Mulawarman setiap musim panen mampu menyumbang 2.630 ton gabah. Kini Desa Mulawarman telah dihuni $812 \mathrm{KK}$. Seiring berjalannya waktu warga Desa Mulawarman dihadapkan sebuah prahara, Pada 2003 PT Kayan Putra Utama Coal (KPUC) dan PT Jembayan Muara Bara (JMB) memulai aktivitas . Pelanpelan persawahan berubah menjadi tambang batu bara. Satu demi satu warga melepas lahan mereka. Tahun 2003-2008, masyarakat menjual dengan harga sangat murah, hanya puluhan juta untuk 1 hektare. Disamping peledakan ladang batu bara membuat banyak rumah retak. 
Aktivitas galian emas hitam yang hanya berjarak 50 meter dari kampung mengirim debu tebal. Sudah tak terhitung warga yang terkena infeksi saluran pernapasan akut.

Desa Mulawarman sebagai desa agraris perlahan sirna mulai tahun 2003. Dikepung dua perusahaan batu bara, PT Kayan Putra Utama Coal (KPUC) dan PT Jembayan Muara Bara (JMB), lahan yang dulunya untuk menghasilkan padi sudah tidak subur lagi, limbah perusahaan mencemari sawah. Pada tahun 2008, masyarakat Desa Mulawarman mendemo BLH (Badan Lingkungan Hidup). Setelah dilakukan pemeriksaan ternyata limbah batu bara masih dalam ambang batas. Dengan demikian masyarakat tidak bisa berbuat apa-apa, karena tidak punya bukti, namun merasakan dampaknya, atas kondisi itulah satu per satu warga menjual tanahnya kepada perusahaan. Warga menjual tanah karena sudah tidak layak untuk bercocok tanam. Keberadaan penambangan batu bara juga menimbulkan efek berantai. Masyarakat kesulitan mendapatkan air bersih akibat terpapar limbah, subsidi dari perusahaan tidak mencukupi. Penambangan itu merugikan masyarakat karena memberikan dampak buruk. Selain sulitnya air bersih, juga bangunan rumah mengalami kertetakan, polusi suara karena teramat bising, rentan longsor, serta debu yang bisa menimbulkan bebagai penyakit. Dampak sosial juga terjadi akibat penambangan perusahaan tersebut. Pada tahun 2014 silam, masyarakat di desa mulawarman pernah terlibat bentrok dengan organisasi masyarakat yang membela perusahaan. Pilihan hanya satu, relokasi atau tutup tambang. Ada tiga alternatif lokasi relokasi yakni, didalam hutan tanaman Sumalindo, Embalut, dan area pasca-tambang milik PT JMB. Namun hal ini belum mendapat kepastian dari pemerintah daerah.

Dengan melihat fenomena yang telah diuraikan di atas, maka masyarakat Desa Mulawarman masih sangat jauh dari kata sejahtera. Hal ini terlihat dari menurunya lahan garapan petani yang hanya tersisi 35 ha itupun juga masuk di areal konsesi perusahaan tambang yang beroperasi, sementara lahan garapan sebelumnya berjumlah 700 ha, bahkan Desa Mulawarman sebagai desa tidak lagi layak untuk menjadi pemukiman masyarakat serta terancam punah oleh aktivitas pertambangan batu bara yang tidak bertanggung jawab. Pemerintah daerah khususnya pemerintah Kabupaten Kutai Kartanegara sebagai tempat masyarakat mendapat perlidungan serta keadilan seolah tidak merespon dan terkesan melakukan pembiaran terhadap persoalan yang dialami masyarakat di Desa Mulawarman Kecamatan Tenggarong Seberang Kabupaten Kutai Kartanegara. Karena permohonan relokasi yang merupakan salah satu solusi untuk menangani persoalan yang terjadi di Desa Mulawarma sudah disampaikan sejak tahun 2010, namun hingga saat ini tidak ada tindak lanjut dari pemerintah maupun pemerintah daerah.

Fenomena tersebut jika dikaitkan dengan konteks aturan dapat dipahami bahwa pemerintah daerah belum mampu menjalankan amanat Undang-undang Nomor 41 tahun 2009 tentang Perlindungan Lahan Pertanian Pangan Berkelanjutan. Dalam pasal 33 (2) menyebutkan bahwa pemerintah dan pemerintah daerah bertanggung jawab terhadap pelaksanaan konservasi tanah dan air, yang maliputi perlindungan, pelestarian. pengelolaan kualitas lahan dan air serta pengendalian pecemaran. Disamping itu secara lebih jelas kembali disebutkan bahwa dalam pasal 35 (1) pemerintah daerah wajib melakukan perlindungan terhadap lahan pertanian pangan berkelanjutan.

Maka dengan demikian menurut hemat penulis pemerintah daerah diharapkan mampu meningkatkan fungsinya untuk mempertahankan eksistensi Desa mulawarman sebagai Desa agraris. Fungsi yang dimaksudkan hal ini ialah fungsi pemerintah daerah Kabupaten Kutai Kartanegara sebagai dinamisator/penggerak dimaksudkan agar pemerintah daerah Kabupaten Kutai Kartanegara dapat menggerakan aspirasi masyarakat khususnya masyarakat yang menjadi korban dari aktivitas pertambangan di Desa Mulawarman.

Penelitian ini diharapkan berkontribusi sebagai pencegahan terhadap kepunahan Desa agraris melalui analisis fungsi pemerintah daerah dalam mempertahankan keberadaan wilayahagraris di Desa. Di lain hal peneliti mempertegas fungsi pemerintah daerah sebagai dinamisator dalam mempertahankan eksistensi d esa agraris berkelanjutan. Disamping itu hasil penelitian dapat mendorong peningkatan fungsi pemerintah daerah dalam penyelenggaraan pemerintahan daerah di era otonomi khususnya dalam konteks pelaksanaan program desa agraris.

Pemerintah daerah khususnya di Kabupaten Kutai Kartanegara saat ini memiliki kecendrungan tidak kontinuitas dalam penyelenggaraan pemerintahan khususnya dalam menata 
pelaksanaan program desaagraris di wilayahnya. Dengan demikian berpotensi menciptakan masalah-masalah baru yang berkaitan dengan kondisi-kondisi lahanpertanian di desa. Maka pemerintah daerah khususnya di Kabupaten Kutai Kartanegara diharapkan mampu menyesuaikan diri dengan kondisi masyarakat khususnya petaniyang semakin dinamis serta pemerintah daerah Kabupaten Kutai Kartanegara harus memaksimalkan fungsinya dalam rangka meningkatkan kesejahteraan maupun pengembangandesaagraris.

Sesuai dengan fenomena yang telah di paparkan diatas, maka rumusan masalah dalam penelitian ina ialah bagaimanaperan pemerintah daerah sebagai dinamisator /penggerak dalam mempertahankan eksistensi Desa Mulawarman sebagai desa agraris?

Menurut [1] Labolo et al. (2015) mengungkapkan bahwa: "Untuk dapat melakukan tugas atau perannya, pemerintah harus mampu menempatkan dirinya di atas, agar supaya ia bisa berperan menggerakkan (sebagai dinamisator) partisipasi masyarkat, ia harus mampu berada di depan rakyat". Pemerintah harus menjadi pembangkit atau penggerak partisipasi seluruh lapisan masyarakat serta harus mampu melihat dan mengantisipasi keadaan, dalam arti lebih baik mencegah akan terjadinya berbagai kemungkinan kendala, dari pada menanggulangi dikemudian hari [2 ] Syafiie (2011)

Pemerintah sebagai dinamisator/penggerak partisipasi masyarakat seperti yang telah disebutkan oleh Labolo dkk, tentunya dapat dipahami bahwa pemerintah pusat maupun daerah memiliki tanggung jawab dalam menjalankan perannya secara menyeluruh agar kebutuhan atau aspirasi masyarakat dapat tercapai termasuk dalam hal ini aspirasi masyarakat pedesaan yang berada dibawah pemerintahan daerah. Oleh karena itu maka tentu pemerintah khususnya pemerintah daerah memiliki peran yang sangat penting dalam mewujudkan segala harapan masyarakat pedesaan dengan kata lain kehidupan masya rakat tidak akan berjalan dengan baik tanpa adanya campur tangan pemerintah daerah. Dengan demikian pemerintah daerah sebagai dinamisator/penggeraka aspirasi masyarakat pedesaan harus mampu menjalankan perannya secara maksimal agar tidak menimbulkan disorientasi pembangunan dan mendapat stigma negatif ditengah-tengah masyarakat pedesaan yang semakin dinamis.

Keberadaan desa-desa dalam suatu daerah tentu memiliki potensinya masing-masing yang kemudian dapat menjadi aset daerah tersebut, melihat kondisi desa-desa yang ada saat ini di indonesia kahususnya desa-desa yang berada di daerah Kabupaten Kutai Kartanegara Provinsi Kalimantan Timur yang mayoritas memiliki potensi di bidang agraris tentunya potensi tersebut merupakan hal yang mestinya dikembangkan dengan baik oleh pemerintah daerah sebagai wujud dalam mendukung perekonomian berkelanjutan. Namun dalam kasus penelitian ini justru desa yang memiliki potensi agraria terancam punah dikarenakan adanya aktivitas pertambangan di Desa tersebut.

Perlu dipahami sebelumhya bahwa i stilah agraria berasal dari Akker (Bahasa Belanda), Agros (Bahasa Yunani) berarti tanah pertanian, Agger (Bahasa Latin) berarti tanah atau sebidang tanah, Agrarius (Bahasa Latin) berarti perladangan, persawahan, pertanian, Agraria (Bahasa Inggris) berarti tanah untuk pertanian [3 ] Santoso (2010). Selanjutnya agraria juga dapat dilihat dari terminologi bahasa, pengertian agraria yang terdapat pada Undang-Undang Pokok Agraria (UUPA). Hal tersebut diketemukan apabila membaca peraturan dan pasal yang terdapat di dalam peraturan Undang-Undang Pokok Agraria. Hukum agraria memiliki arti atau makna yang luas. Pengertian bumi meliputi permukaan bumi (yang disebut tanah), tubuh bumi dibawahnya serta yang berada di bawah air (pasal 1 ayat 4 dan pasal 4 ayat 1 ) [4] Supriadi (2012).

Sebelumnya, telah banyak penelitian yang dilakukan terkait dengan bidang agraris diantaranya [5] Nurif (2010) yang mengkaji pembangunan ekonomi berbasis agribisnis sebagai wujud dari pembangunan ekonomi yang berkelanjutanDalam penelitian ini disajikan bahwa pembangunan ekonomi berbasis agribisnis merupakan strategi pembangunan ekonomi yang berbasis pada pendayagunaan kemampuan rakyat banyak. Sedangkan kegiatan agribisnis melingkupi sektor pertanian, termasuk perikanan dan kehutanan, se rta bagian dari sektor industri. [6] Arvianti (2018) penelitian tersebut menemukan bahwa permasalahan alih fungsi lahan diperparah oleh kelembagaan dan sumber daya manusia petani yang masih lemah, mengingat tenaga kerja sektor pertanian hari ini rata-rata merupakan petani berusia lebih dari 50 tahun. Usia yang terbilang tua menjadi kendala dalam penguasaan teknologi pertanian dan 
kemampuan kerja, sehingga mempengaruhi tingkat produksi dan berdampak pada perolehan pendapatan yang rendah.

selanjutnya penelitian oleh [7] Suranta (2012) Dalam penelitian ini disajikan bagaimana cara untuk dapat memiliki hak tanah yang ada di Indonesa, yaitu dengan mendaftarkan tanahnya kepada Pejabat Pembuat Akta Tanah (PPAT). Upaya yang dilakukan oleh PPAT dalam membantu pemilik hak dalam mencapai jaminan dan kepastian hukum hak atas tanah adalah dengan dilakukannya pendaftaran tanah di seluruh wilayah Republik Indonesia. Pada kegiatan ini telah diadakan pengukuran, pemetaan, pembukuan tanah, pendaftaran peralihan atas tanah yang selanjutnya kemudian terhadap itu dilakukan pula pemberian surat-surat tanda bukti yang dikenal dengan "sertifikat" (PP No.24 Tahun 1997 tentang Pendaftaran Tanah) . Adapun penelitian yang dilakukan [8] Andri (2016) yang meyakini bahwa, hilangnya lahan berarti juga merubah lahan usaha bagi mereka. Mereka yang beralih mata pencaharian ke sektor perikanan dihadapkan banyak kendala. Perkembangan sektor perdagangan dan jasa sangat dipengaruhi oleh situasi desa yang ada. Perubahan juga mengakibatkan memudarnya lembaga tradisional yang biasa hidup dalam masyarakat agraris. Juga terjadi degradasi dalam birokrasi desa dan perubahan tipe ekonomi keluarga dari basis ke tipe upahan. Anggota keluarga yang tadinya memiliki sikap familinisme kuat berubah ke individualisme.

Dari telaah penelitian di atas, maka penulis mendapatkan beberapa poin penting yang dapat menjadi bahan pertimbangan untuk melakukan penelitian. Karena ketika berbicara tentang fungsi pemerintah daerah khususnya dalam mempertahankan keberadaan desa agraris tentu memiliki permasalahan yang sangat kompleks, maka dari itu beberapa penelitian terdahulu yang telah diuraikan di atas dimaksudkan dapat memberikan batasan bagi peneliti dalam melanjutkan penelitian dan terciptanya suatu hasi penelitian spesifik yang memberikan sumbangsi baru terhadap pengembangan dan pelestarian desa agraris kedepannya secara berkesinambungan.

\section{METODE PENELITIAN}

Metode yang digunakan dalam penelitian ini adalah metode kualitatif dengan pendekatan studi kasus, metode ini dianggap relevan dengan penelitian yang akan dilakukan untuk memperoleh pemahaman yang sebenarnya mengenai peran pemerintah daerah sebagai dinamisator/penggerak dalam mempertahankan eksistensi desa mulawarman sebagai desa agraris. Disamping itu dengan metode kualitatif, diharapkan mampu mengesplorasi dan memahami makna dari sebuat masalah yang akan dikaji. Proses penelitian ini melibatkan upaya-upaya penting, seperti mengajukan pertanyaan-pertanyaan dan prosedur-prosedur, mengunpulkan data secara induktif mulai dari tema-tema yang khusus ke tema-tema umum, dan menafsirkan makna data [9] Creswell (2016).Disamping itu penelitian dengan metode kualitatif melibatkan penulis sebagai instrumen kunci dalam penelitian, dengan demikian informasi dan data terkait dengan konteks penelitian peran pemerintah daerah sebagai dinamisator/penggerak dalam mepertahankan eksistensi desa agraris diperolah dari interaksi langsung penulis dengan para pertisipan dalam penelitian ini. Sehingga informasi dan data penelitian yang diproleh oleh penulis sesuai dengan apa yang terjadi dilapangan dan tidak dimanipulasi.

Creswell menambahkan penelitian kualitatif tidak hanya bertumpu pada satu sumber data. Sumber data utama dalam penelitian kualitatif adalah kata-kata, dan tindakan, selebihnya adalah data tambahan seperti dokumen dan lain-lain. Berkaitan dengan hal itu jenis data dibagi kedalam kata-kata dan $\mathrm{t}$ indakan, sumber data tertulis, foto, dan statistik [10] (Lofland dan Lofland dalam Moleong, 2005) Moleong (2004). Beberapa sumber data tersebut dapat diperoleh melalui teknik seperti:Observasi, wawancara, dan dokumentasi.

\section{HASIL DAN PEMBAHASAN}

Dalam konteks pemerintah daerah Kabupaten Kutai Kartanegar sebagai dinamisator/penggerak aspirasi masyarakat dalam mempertahankan keberadan desa agararis Pemukiman Trasmigrasi 
Kabupaten Kutai Kartanegara menyebutkan bahwa: setiap Unit Pemukiman Transmigrasi (UPT) telah ditempat kepala UPT yang mewakili Dinas terkait. Biasanya di tempatkan dua atau tiga orang untuk setiap anggota perwakilan UPT, dengan kemudian aspirasi masyarakat disampaikan ke Dinas terkait kamudian Dinas tersebut menyampaikan ke DPRD sebagai perwakilan rakyat.

pemerintah daerah Kabupaten Kutai Kartanegara dalam menjalankan perannya sebagai dianamisator /penggerak aspirasi masyarakat tentu harus di ukur dengan penacapaian yang ada saat ini, karena pada kenyataannya dengan apa yang dilakukan oleh pemerintah daerah Kabupaten Kutai Kartanegara dalam mewujudkan pembangunan yang sesuai dengan skala prioritas masyarakan atau berdasarkan aspirasi masyarakat Desa Mulawarman tentu belum dapat terelisasi dengan baik. Kondisi di Desa Mulawarman sebagai desa agraris sebagaim ana yang telah disampaikan pada bagain pendahuluan bahwa pemerintah daerah Kabupaten Kutai Kartanegara belum sepenuhnya dapat memberikan langkah solutif dalam mengatasi permasalahan lahan pertanian dan pembangunan infrastruktur jalan yang manjadi pendukung dalam meningkatkan kesejahteraan masyarakat di Desa Mulawarman.

Dalam mempertahankaneksistensi Desa Mulawarman sebagai desa agraris, pemerintah Kabupaten Kutai Kartanegara menghindar penyelesaian masalah dengan pola Top Down atau dari atas kebawah, namun memilih pendekatan dengan turun langsung kemasyarakat yang bersangkutan untuk mendiskusikan kemudian dengan melibatkan perusahaan terkait sehingga semua pihak dapat memahami dan mengetahui serta menyetujui mengenai apa yang akan dilakukan oleh pemerintah daerah Kabupaten Kutai Kartanegara.

Peran pemerintah daerah Kabupaten Kutai Kartanegara sebagai dinamisator atau penggerak aspirasi masyarakat pedesaan tentu tidak dapat hanya dimaknai dengan turunnya pemerintah daerah Kabupaten Kutai Kartanegara langsung kepada masyarakat untuk mendengarkan aspirasi masyarakat kemudian menjadi perencanaan yang disepakati dengan masyarakat Desa Mulawarman dengan pihak-pihak yang terkait. Akan tetapi peran sebagai dinamisator/penggerak tersebut dimaknai sebagai respon pemerintah daerah Kabupaten Kutai Kartanegara dalam bertindak tegas dan cepat serta terealisasi nyata dalam mengatasi permasalahan keberadaan Desa Mulawarman sebagai desa agraris terancam punah.

Persoalan kemudian jika pemerintah daerah Kabupaten Kutai Kartanegara tidak memiliki langkah-langkah yang solutif serta dapat direalisasikan dengan baik, maka tentu akan berimbas pada bertambahnya masalah baru bagi masyarakat di Desa Mulawarman, $m$ aka dengan demikian pemerintah daerah Kabupaten Kutia Kartanegara sebagai pihak yang diberikan tanggung jawab untuk merealisasikan aspirasi masyarakat desa diibaratkan seperti pepatah yang mengatakan bahwa "lebih baik mencegah dari pada mengobati".

Kondisi Desa Mulawarman bukanlah persoalan yang biasa malainkan persoalan tersebut apabila dibiarkan dengan berlarut maka bukan hanya mengacam habisnya lahan-lahan pertanian masyarakat Desa Mulawarman, namun lebih dari pada itu akan mengancam nyawa bagi masyarakat itu sendiri yang tinggal di desa tersebut tersebut,Karena saat ini jarak Desa Mulawarman dengan lokasi pertambangan batu bara hanya sekitar 60 meter, kondisi lingkungan sudah tidak sehat karena terkepung perusahaan tambang, banyak anak-anak balita yang terserang ISPA (Infeksi Saluran Pernafasan Atas . Sementara menurut masyarakat Desa Mulawarman mengetakan bahwa, kondisi keberadaan Desa Mulawarman saat ini sangat memprihatinkan salah satu contoh, jika kemarau sampai sepuluh (10) hari saja masyarakat sudah mulai kesulitan dengan kebutuhan air bersih untuk sehari-hari. P ernyataan tersebut memestikan bahwa apa yang menjadi tanggung jawab pemerintah daerah Kabupaten Kutai Kartanegara sebagai dinamisator/penggerak aspirasi masyarakat dalam menunjang apa yang menjadi kebutuhan prioritas masyarakat Desa Mulawarman, masih jauh dari apa yang diharapkan oleh masyarakat setempat. Pengembangan Desa Mulawarman sebagai desa agraris yang seperti diharapkan oleh masyarakat hanya menjadi sebuah harapan yang tidak memiliki kepastian dari pemerintah daerah Kabupaten Kutai Kartanegara. Sebagai masyarakat Desa Mulawarman tentu hanya menggantungkan nasib pada pemerintah daerah Kabupaten Kutai Kartanegara tanpa bisa berbuat banyak terhadap masalah yang dihadapinya. Meskipun demikian masyarakat Desa Mulawarman tetap memil ih untuk bertahan tetap tinggal di desa tersebut, walaupun sewaktu-waktu kondisi desa mulawarman bisa mengancam nyawa masyarakat yang 
disebabkan oleh pencemaran pertambangan batu bara. Hal ini sesuai pernyataan Kepala Dusun Karya Bakti Desa Mu lawarman yang menyebutkan bahwa, jarak pemukiman transmigrasi di Desa Mulawarman dengan perusahaan tambang sangat dekat, sehingga disini kalau tidak hujan selama seminggu, maka pencemaran debu yang disebabkan dari perusahaan tambang sangat mengganggu kesehatan masyarakat, meskipun ada konvensasi dari perusahaan tambang sekitar Rp. 300.000 setiap bulan untuk setiap kepala keluarga, akan tetapi itu tidak sebanding dengan dampak yang dirasakan oleh masyarakat Desa Mulawarman yang juga kehilangan lahan pertanian.

Sehubungan dengan penjelasan di atas, maka apa yang menjadi peran pemerintah daerah Kabupaten Kutai Kartanegara sebagai dinamisator atau penggerak aspirasi masyarakat dalam menciptakan pembangunan desa serta kemandirian masyarakat di pedesaan bukanlah hal yang mudah meskipun Desa Mulawarman pernah manjadi lumbung pada.

Dengan demikian pemerintah daerah Kabupaten Kutai Kartanegara belum mamiliki paradigma baru dalam menanggapi serta menyelesaikan persoalan yang terjadi di Desa Mulawarman, apabila pemerintah daerah Kabupaten Kutai Kartanegar tidak cermat dalam menyelesaikan persoalan keberadaan Desa Mulawarman saat ini, maka tidak menutup kemungkinan permasalahan serupa akan muncul di Desa lainnya yang berada di daerah sekitar Desa Mulawarman.

Pengembangan desa agraris di Kebupeten Kutai Kartanegara bukanlah hal yang tidak mungkin untuk dilakukan apabila pemerintah daerah Kabupaten Kutai Kartanegara memiliki perencanaan yang memadai serta melibatkan semua pihak yang bertanggung jawab dalam konteks pengembangan desa agraris. Beberapa aspek yang menjadi pertimbangan bagi pemerintah daera Kabupaten Kutai Kartanegara dalam mempertahankan keberadaan Desa Mulawarman sebagai desa agraris dan bisa menjadi peluang untuk mengatasi permasalahan Desa Mulawarman di antaranya menekan pihak perusahaan pertambangan untuk ikut memperhatikan desadesa yang berada disekitar perusahan, ini sangat memungkinkan untuk dilakukan oleh pemerintah daerah Kabupaten Kutai Kartanegara dengan memberikan ketegasan berupat aturaan maupun pengentrolan berkala bagi pihak perusahaan tambang.

Eveluasi terhadap perusahaan-perusahaan tambang yang berada di Desa Mulawarman dalam artian bagaimana pemerintah daerah Kabupaten Kutai Kartanegara dapat malihat jarak tambang, potensi pencemarannya, dan kemudian melihat alih fungsi lahan masyarakat di Desa Mulawarman, karena perusahaan tambang batu bara tidak hanya merusak areal tambang itu sendiri melainkan akan merusak semua areal lahan-lahan produktif disekitarnya.

Penyelesaian permasalahan yang terjadi di desa Mulawarman tidaklah cukup jika hanya mengatasi persoalan yang muncul dipermukaan saja. Melainkan dalam menyelesaikan persoalan tersebut perlu dilihat dari akar permasalahan yang menjadi penyebab utama agar apa yang menjadi masalah di Desa Mulawarman tidak kembali terulang.

Permasalahan yang terjadi di Desa Mulawarman sangat berdampak terhadap melemahnya sektor ekonomi yang disebabkan oleh kurangnya lahan produktif yang dapat menjadi pendukung usaha pertanian masyarakat. Lahan pertanian di Desa Mulawarman dengan luas lahan sawah sekitar $450 \mathrm{Ha}$, dulunya sangat memadai untuk peningkatan kesejahteraan masyarakat di Desa Mulawarman, namun saat ini lahan persawahan tersebut hanya tersisa sekitar $20 \mathrm{Ha}$.

Di samping itu permasalahan pembangunan infrastruktur juga menjadi salah satu penyebab dalam pengembangan Desa Mulawarman sebagai desa agraris. Apabila pemerintah daerah Kabupaten Kutai Kartanegara tidak merespon cepat apa yang menjadi aspirasi dan kebutuhan masyarakat di Desa Mulawarman seperti percetakan sawah baru untuk lahan usaha masyarakat dan perbaikan jalan, tentu ini akan memberikan dampak negatif yang berkepanjangan bagi masyarakat di Desa Mulawarman.

Pada kondisi ini pemerintah daerah Kabupaten Kutai Kartanegara dituntut untuk berada didepan masyarakat Desa Mulawarman sebagai penggerak atau pembangkit aspirasi masyarakat dalam mewujudkan dan memberikan pengharapan pada masyarakat dalam pengembangan Desa Mulawarman yang berkelanjutan agar masyarakat tidak merasa terisolasi dengan kondisi yang terjadi saat ini. Desa Mulawarman yang layak huni, layak usaha dan layak berkembang tidak hanya akan tercipta tanpa adanya perencanaan yang strategis dari pemerintah daerah Kabupaten Kutai Kartanegara dengan menyesuaikan kebutuhan masyarakat 
setempat.

Pemerintah daerah Kabupaetan Kutai Kartanegara sebagai dinamisator atau penggerak aspirasi masyarakat dalam mempertahankan keberadaan Desa Mulawarman sebagai desa agraris belum mampu terwujud sesuai dengan apa yang menjadi keinginan masyarakat di Desa Mulawarman. Sehingga kemudian kondisi ini memberikan sebuah pandangan bahwa apa yang menjadi kewajiban pemerintah daerah Kabupaten Kutai Kartanegara dalam merespon aspirasi masyarakat, belum dapat dirasakan oleh masyarakat yang berada di Desa Mulawarman. Hingga kemudian terancam punahnya lahan-lahan pertanian masyarakat tersebut.

\section{Partisipasi Masyarakat Dalam Mendorong Pembangunan Dan Kemandirian Masyarakat Desa Mulawarman}

Keterlibatan masyarakat dalan pembangunan merupakan bagian yang menjadi syarat dalam menciptakan pembangunan yang berkeadilan dan dapat sesuai dengan skala prioritas kebutuhan masyarakat di pedesaan. Dalam upaya mempertahankan keberadaan Desa Mulawarman sebagai desa agraris dapat dilakukan dengan cara keterlibatan aktif pemerintah daerah Kabupaten Kutai Kartanegara sebagai dinamisator atau penggerak aspirasi masyarakat, dengan demikian maka pemerintah daerah Kabupaten Kutai Kartanegara dapat menentukan suatu perencanaan pembangunan yang beorientasi pada skala prioritas kebutuhan masyarakat Desa Mulawarman. Oleh sebab itu peran pemerintah daerah Kabupaten Kutai Kartanegara sebagai dinamisator/penggerak merupakan bagian yang tidak terpisahkan dalam menjaga dan melestarikan desa agraris.

Merujuk pada pemahaman di atas dan kembali dikaitkan dengan fenomena yang terjadi pada Desa Mulawarman. Dalam upaya mendorong pembangunan dan kemandirian masyarakat di Desa Mulawarman, sudah selayaknya mendapatkan apa yang menjadi kebutuhannya dalam mengatasi masalah yang dihadapinya saat ini. Namun persoalan kemudian dari apa yang menjadi tuntutan dan aspirasi masyarakat Desa Mulawarman hanya sampai di tengah jalan, karena hingga saat ini belum terdapat realisasi dari pemerintah daerah Kabupaten Kutai Kartanegara sebagai bentuk keseriusan dalam mengatasi persoalan Desa Mulawarman, maka hal yang wajar jika kepercayaan masyarakat terhadap pemerintah daerah Kabupaten Kutai Kartanegara semakin menimbulkan tanda tanya. Terlebih lagi bahwa sebelumnya pemerintah desa Mulawarman sempat meminta bantuan pada pemerintah pusat tekait persoalan ketersediayaan lahan-lahan pertaniang yang telah dicemari oleh pertambangan dan bahkan seiting dengan waktu lahan pertanian semakin berkurang.

Apa yang menjadi poin penting dari pejelasan di atas tentu dapat dipahami bahwa lemahnya atensi pemerintah daerah Kabupaten Kutai Kartanegara terhadap penyelesaian masalah Desa Mulawarman yang memaksa masyarakat mengam bil jalan akhir untuk meminta bantuan kepada pemerintah pusat, meskipun hal itu merupakan hal yang tidak wajar untuk dilakukan oleh masyarakat di Desa Mulawarman, karena mengingat bahwa pada tingkatan pemerintahan masih terdapat pemerintah daerah Kabupaten Kutai Kartanegara yang dianggap paling memahami dan memiliki tanggung jawab terhadap segala permasalahan yang dialami oleh masyarakat pedesaan di daerahnya.

Dengan demikian dalam konteks peran pemerintah daerah Kabupaten Kutai Kartanegara sebagai dinamisator/penggerak dalam menjaga dan mempertahankan keberadaan Desa Mulawarman sebagai desa agraris tentu dapat dipastikan bahwa peran tersebut masih manjadi peran yang belum mampu untuk dioptimal oleh pemerintah daerah Kabupaten Kutai Kartanegara dan pada akhirnya menimbulkan dampak yang mengancam keberadaan Desa Mulawarman. Hal ini merupakan koreksi nyata yang menjadi perhatian bersama bahwa dalam mengembangakan desa agraris, pemerintah daerah masih sulit untuk sampai pada tahap kemandirian perekonomian desa agraris yang berkelanjutan. Apabila peran pemerintah daerah Kabupaten Kutai Kartanegara sebagai dinamisator/penggerak tersebut tidak berjalan dengan baik dalam memepertahankan keberadaan desa agraris, maka tentu pembangunan desa agraris akan mengalami disorientasi dari apa yang manjadi cita-cita hadirnya desa agraris yang memiliki multidimensi dalam artian sebagai wujud pembangunan ekonomi, politik, dan sosial budaya bagi 


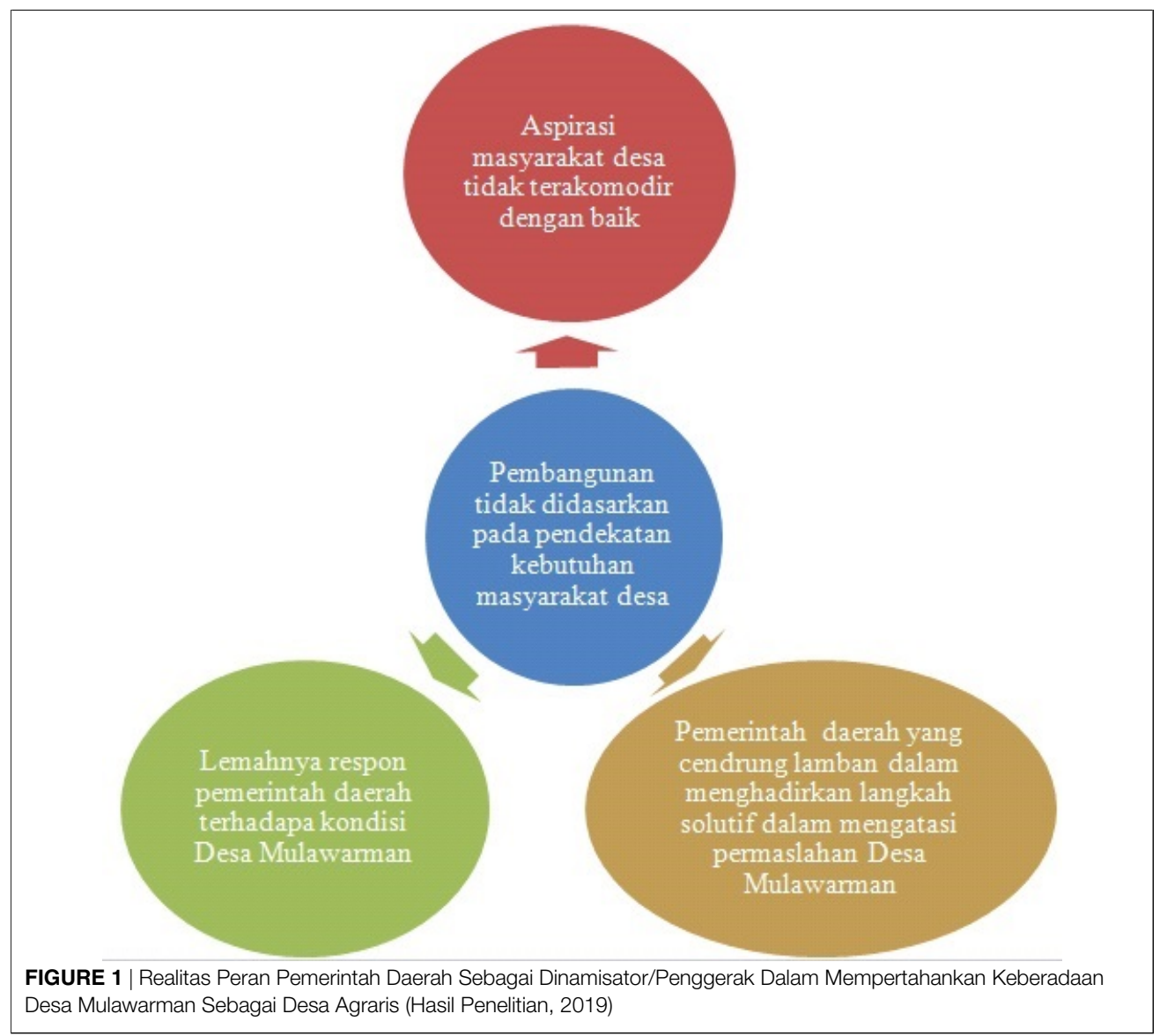

daerah Kabupaten Kutai Kartanegara sebagai daerah yang memiliki potensi desa-desa dibidang agraris.

\section{KESIMPULAN}

Peran pemerintah daerah Kabupaten Kutai Kartanegara sebagai dinamisator/penggerak dalam mempertahankan keberadaan Desa Mulawarman sebagai desa agraris dapat diketahui bahwa, pemerintah daerah Kabupaten Kutai Kartanegara dalam melaksanakan perannya sebagai dinamisator atau penggerak aspirasi masyarakat Desa Mulawarman cendrung kurang mengedepankan pendekatan kebutuhan masyarakat Desa Mulawarman, sehingga pembangunan yang dilakukan oleh pemerintah daerah Kabupaten Kutai Kartanegara dalam mendorong kemandirian ekonomi masyarakat Desa Mulawarman masih bersifat stagnasi. Hal ini di ketahui karena apa yang menjadi aspirasi masyarakat Desa Mulawarman belum dapat terwujud untuk mengatasi permasalahan kondisi lahan pertanian di Desa Mulawarman yang semakin berkurang. Masyarakat Desa Mulawarman hanya dihadapkan dua pilihan yaitu relokasi atau pengembalikan bidang pertanian masyarakat desa melalui penyediaan lahan baru usaha pertanian serta segala ketersediaan fasilitas yang dapat menunjang aktivitas pertanian masyarakat Desa Mulawarma n, diantara pilihan tersebut hingga saat ini belum membuahkan hasil di tengah-tengah kesulitan masyarakat Desa Mulawarman. Sementara itu karena kurangnya respon pemerintah daerah Kabupaten Kutai Kartanegara dalam menanggapi apa yang menjadi kebutuhan masyarakat Desa Mulawarman, maka dalam segalah upaya pemerintah Desa Mulawarman beserta masyarakat setempat meminta bantuan kepada pemerintah pusat untuk menyelesaikan persoalan yang dialami masyarakat Desa Mulawarman. Hal ini semakin menunjukkan bahwa peran pemerintah daerah Kabupaten Kutai Kartanegara 
sebagai dinamisator/penggerak aspirasi masih sangat jauh dari orientasi dalam menyelesaikan persoalan Desa Mulawarman. Sehingga kemudian peran pemerintah daerah Kabupaten Kutai Kartanegara sebagai dinamisator/penggerak yang kurang optimal dalam konteks mempertahankan keberadaan Desa Mulawarman sebagai desa agraris menjadi salah satu penyebab utama atas permasalahan yang terjadi pada Desa Mulawarman saat ini dan tidak menutup kemungkinan persoalan tersebut juga akan terjadi pada desa-desa lainnya di Kabupaten Kutai Kartanegara.

\section{REFERENCES}

Andri, K. B. (2016). Sejarah Perubahan Sosial Masyarakat Agraris Akibat Pembangunan Waduk di Banjarnegara, Jawa Tengah. Jurnal Agriekonomika 5.

Arvianti, E. Y. (2018). Karakteristik Petani Muda Agribisnis dan Faktor-Faktor yang Mempengaruhi Alih Fungsi Lahan di Malang. Jurnal Sosial Ekonomi dan Kebijakan Pertanian 7.

Creswell, J. W. (2016). Reserarch Desaign: Pendekatan Metode Kualitatif, Kuantitatif, dan Campuran (Yogyakarta: Pustaka Pelajar).

Labolo et al. (2015). Dialektika Ilmu Pemerintahan (Bogor: Ghalia Indonesia), 135.

Moleong, L. J. (2004). Metodologi Penelitian Kualitatif (Bandung: Remaja Rosda Karya).

Nurif, M. (2010). Pembangunan Ekonomi Berbasis Agribisnis sebagai Wujud dari Pembangunan Ekonomi yang Berkelanjutan 3, 124-138.

Santoso, U. (2010). Hukum Agraria Dan Hak-Hak Atas Tanah (Jakarta: Kencana Prenada Group).

Supriadi (2012). Hukum Agraria (Jakarta: Sinar Grafika).
Suranta, F. A. (2012). Fungsi Pendapatan Tanah di Indonesia Ditinjau Menurut Undang-Undang Pokok Agraria. Jurnal Mercatoria 5.

Syafiie, I. K. (2011). Etika Pemerintahan: Dari Keseimbangan Good Governamce dengan Clean Government: Ilmu Pemerintahan Dalam Mengubah Pemerinta++++++ab Menjadi Pemerintah Beradab (Jakarta: Rineka Cipta), 203.

Conflict of Interest Statement: The authors declare that the research was conducted in the absence of any commercial or financial relationships that could be construed as a potential conflict of interest.

Copyright (C) 2019, , Mulka and Santi. This is an open-access article distributed under the terms of the Creative Commons Attribution License (CC BY). The use, distribution or reproduction in other forums is permitted, provided the original author(s) and the copyright owner(s) are credited and that the original publication in this journal is cited, in accordance with accepted academic practice. No use, distribution or reproduction is permitted which does not comply with these terms. 